\title{
Timothy Chesters, Flaubert's reading notes on Montaigne
}

Damiano Sinfonico

\section{(2) OpenEdition}

1 Journals

\section{Edizione digitale}

URL: http://journals.openedition.org/studifrancesi/6370

DOI: $10.4000 /$ studifrancesi.6370

ISSN: 2421-5856

\section{Editore}

Rosenberg \& Sellier

\section{Edizione cartacea}

Data di pubblicazione: 1 novembre 2010

Paginazione: $573-574$

ISSN: 0039-2944

\section{Notizia bibliografica digitale}

Damiano Sinfonico, «Timothy Chesters, Flaubert's reading notes on Montaigne», Studi Francesi [Online], 162 (LIV | III) | 2010, online dal 30 novembre 2015, consultato il 09 janvier 2021. URL: http:// journals.openedition.org/studifrancesi/6370 ; DOI: https://doi.org/10.4000/studifrancesi.6370

Questo documento è stato generato automaticamente il 9 janvier 2021.

\section{(c) $(1) \&$}

Studi Francesi è distribuita con Licenza Creative Commons Attribuzione - Non commerciale - Non opere derivate 4.0 Internazionale. 


\title{
Timothy Chesters, Flaubert's reading notes on Montaigne
}

\author{
Damiano Sinfonico
}

\section{NOTIZIA}

TIMOTHY CHESTERS, Flaubert's reading notes on Montaigne, in «French Studies», volume

LXIII, 4, october 2009, pp. 399-415.

1 La relazione Montaigne-Flaubert si arricchisce di questo nuovo studio, appoggiato al ritrovato manoscritto in cui un Flaubert non ancora ventenne aveva iniziato a chiosare l'amato scrittore. Il quaderno, sparito assieme a circa altri trenta quando l'eredità di Flaubert fu messa all'asta alla morte della nipote, nel 1931, è stato ritrovato dall'A. nel 2008 in una collezione privata inglese. La datazione del manoscritto, di circa ottanta pagine, di cui sessanta dedicate agli Essais e venti al Journal du voyage, risalirebbe al periodo compreso tra il 1838 e i primi anni ' 40 .

2 L'A. individua in esso i motivi di una passione per Montaigne, le contraddizioni di un pensatore in cui Flaubert ha potuto vedere riflesse le proprie, fino a quella estrema tra lo scetticismo e un precoce (e ante litteram) bovarysmo. Più rilevante ancora l'ammirazione per lo stile: l'A. la inquadra nella controversa recezione che Montaigne ha attraversato nella prima metà del secolo, trovando in Flaubert uno dei primi e più originali ammiratori. Flaubert è stato forse il primo a considerare Montaigne un artista, per il quale scrivere è difficile e gli Essais il baluginio fioco di un bello inafferrabile. 